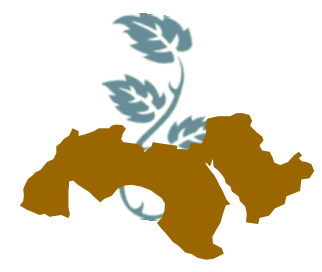

Arab Univ.

J. Agric. Sci., Ain Shams Univ., Cairo, 25(2), 299 - 317, 2017

\title{
EFFECT OF IRRIGATION WITH THREE DIFFERENT WATER RESOURCES ON SOIL CHEMICAL PROPERTIES OF KAFR-SAQR, EI-SHARKIA, EGYPT
}

\author{
Shaimaa. M. EI-Nasharty ${ }^{3}$; M.E. EI-Nennah ${ }^{1}$; A.S. EI-Sebaay ${ }^{1}$ and \\ G. Abd El-Nasser ${ }^{2}$
}

[21]

1- Soil Science Dept., Faculty of Agriculture, Ain Shams University, Cairo, Egypt

2- Ground Water Research Institute, National Water Research Center, El-Qanater El-Khayria, Egypt

3- Soil Dept., Central Laboratory for Environmental Quality Monitoring, National Water Research Center, El-Qanater El-Khayria, Egypt

Keywords: Irrigation water, Soil, Chemical properties

\section{ABSTRACT}

Three irrigation water resources were chosen at Kafr-Saqr district, El-Sharkia Governorate to assess their qualities and their impact on soil properties. The chosen irrigation water were fresh, mixed, and drainage water applied during the two successive seasons of winter-summer of (2013 and 2014). Soil samples were collected from each location at four depths (0-20, 20-40, 40-60 and 60$100 \mathrm{~cm}$ ). Results showed EC values of mixed and drainage water were above the normal range (which should be $<0.7 \mathrm{dS} . \mathrm{m}^{-1)}$ ). Also, the mixed and drainage irrigation waters had approximately 3.5 and 5.6 folds the salinity of the fresh water. Mean $\mathrm{pH}$ values of the collected irrigation water samples were within the permissible limits (6.5 to 8.4). TDS values of the fresh water were within the normal range $\left(<450 \mathrm{mg} \cdot \mathrm{L}^{-1}\right)$. Meanwhile, mixed and drainage water were classified as of slightly and moderately salinity hazards. The highest values of turbidity were found in the drainage water, then mixed and fresh water. SAR values of fresh water were $<1.0$. The SAR values for mixed and drainage waters ranged from 2.62 to 2.69 and from 3.68 to 3.76 , respectively. BOD and COD values violated the standard limits of law 48/1982 (10 $\mathrm{mg} \cdot \mathrm{L}^{-1}$ for drainage water and $6 \mathrm{mg} \cdot \mathrm{L}^{-1}$ for fresh water) except for the BOD values of fresh water. The increase in $\mathrm{pH}$ values for the soil irrigated with the mixed and drainage. The continuous irrigation of soil by wastewater resulted in continuous in- crease in EC values. As well as, increase the amount of total soluble salts in all layers. The application of the different irrigation waters led to increase in soluble ion.

\section{INTRODUCTION}

The shortage of water resources of good quality is becoming an important issue in the arid and semi-arid zones. Fresh water resources in Egypt are limited as well as any future increase in its amounts will be directed mainly to municipal and industrial demands. Consequently, the share for agricultural demand will decrease. For this reason, Water resources of marginal quality such as drainage water, saline groundwater and treated wastewater have become of important consideration. Nevertheless, the use of these waters in irrigated lands requires the control of soil salinity through applying leaching requirements under efficient drainage system to getting of excess water and salts, according to Drainage Research Institute (2005), the drainage water used unofficially reached $1.903 \times 10^{9} \mathrm{~m}^{3}$ from Bahr Hadus main drain water. Suspended solids in water may involve inorganic or organic particles of immiscible liquids. Inorganic solids such as clay, silt and other solids constituents are common in surface water. Organic material such as plant fibers and biological solids (algae cells) are also common constituents in surface water (Peavy et al 1986). The use of drainage water officially and unofficially is controlled by the salts content of the cultivated soils, Continuous irrigation with wastewater generally add significant quantities of salts to the soil envi- 
ronment, such as sulphates, phosphates, bicarbonates, and chlorides, as well as cations of sodium, potassium, calcium and magnesium. The total impact of these salts may increase soil salinity to extreme levels unless leaching by rainfall, clean water or excess irrigation (Patterson, 1999). The salts contents of the irrigation water (fresh, mixed, and drainage) should be less than the salts content in the soil. Many pump stations are used to mix drainage water with fresh water; most of them are located in the Nile Delta regions (east, middle, and west) according to the recommendations of the Ministry of Water Resources and Irrigation. In some other areas, the drainage water is used unofficially by the farmers, especially at the tail end of the irrigation canals, which suffer from shortage in fresh water needed for irrigation. This study aims at investigating the impact of different irrigation water resources on some soil characteristics in Kafr-Saqr district EL-Sharkia Governorate.

\section{MATERIALS AND METHODS}

This work aims at evaluating the impact of different irrigation water resources on some characteristics of the soil, The three soil locations which were selected to represent the soil irrigated with different water resources were as follow: The first location (I): soil irrigated with fresh water (The Nile water) from Bahr Muways canal. This location is represented by the area of Abo-Hammudah Village. The second location (II): soil irrigated with mixed water at the ratio of $(1: 1)$, the fresh water from Bahr Muways Canal, and the drainage water from Masraf Bahr Hadus. Mixing of water was carried out using Hanut pumping station. This location is represented by the area of Ahmed Abd-Allah Village. The Third location (III): soil irrigated with drainage water from Bahr Hadus district. This location is represented by the area of Ezbet elKobre. The water used for irrigating in the different soil locations for aperiod of about thirty years. Soil, irrigation water were sampled, and the study was carried out through two cultivation seasons of `2013` and `2014`.

\section{Soil sampling and analyses}

Three soil profiles were dug to the depth of 100 $\mathrm{cm}$ at each location. Soil samples were collected from successive depths of $0-20,20-40,40-60$ and $60-100 \mathrm{~cm}$. soil samples were collected to determine the chemical characteristics. These collected samples were kept in polyethylene bags and stored in an ice cooler box and delivered immediately to the laboratory where they. Soil samples were air dried, crushed then sieved through $(2 \mathrm{~mm})$ sieve and kept for the following determinations: Total soluble salt, Soluble cations and anions and $\mathrm{pH}$ values according to the methods described by Page et al (1982). Soil samples were extracted by DTPA for $\mathrm{Pb}, \mathrm{Cu}, \mathrm{Fe}, \mathrm{Cd}$ and $\mathrm{Zn}$ and according to Lindsay and Norvel (1978).

Table 1. Mean values of the particle size distribution of the studied soil locations

\begin{tabular}{|c|c|c|c|c|c|}
\hline Location & $\begin{array}{c}\text { Depth } \\
(\mathbf{c m})\end{array}$ & Sand & Silt & Clay & $\begin{array}{c}\text { Texture } \\
\text { class }\end{array}$ \\
\hline \multirow{2}{*}{ I } & $\mathbf{0 0 - 2 0}$ & 32.83 & 31.55 & 35.62 & Clay loam \\
$\mathbf{2 0}-\mathbf{4 0}$ & 30.15 & 33.95 & 35.90 & Clay loam \\
& $\mathbf{4 0 - 6 0}$ & 29.93 & 33.00 & 37.07 & Clay loam \\
& $\mathbf{6 0 - 1 0 0}$ & 27.35 & 37.83 & 34.82 & Clay loam \\
\hline \multirow{3}{*}{ II } & $\mathbf{0 0 - 2 0}$ & 28.14 & 34.62 & 37.24 & Clay loam \\
& $\mathbf{2 0 - 4 0}$ & 28.31 & 31.16 & 40.53 & Clay \\
& $\mathbf{4 0 - 6 0}$ & 26.03 & 33.74 & 40.23 & Clay \\
& $\mathbf{6 0 - 1 0 0}$ & 24.34 & 34.80 & 40.86 & Clay \\
\hline \multirow{2}{*}{ III } & $\mathbf{0 0 - 2 0}$ & 28.05 & 31.47 & 40.48 & Clay \\
& $\mathbf{2 0 - 4 0}$ & 25.08 & 34.57 & 40.35 & Clay \\
& $\mathbf{4 0 - 6 0}$ & 21.7 & 34.18 & 44.12 & Clay \\
& $\mathbf{6 0 - 1 0 0}$ & 22.19 & 33.78 & 44.03 & Clay \\
\hline
\end{tabular}

These collected samples were kept in polyethylene bags and stored in an ice cooler box and delivered immediately to the laboratory where they. Soil samples were air dried, crushed then sieved through $(2 \mathrm{~mm})$ sieve and kept for the following determinations: total soluble salt, Soluble cations and anions and $\mathrm{pH}$ values according to the methods described by Page et al (1982). Soil samples were extracted by DTPA for $\mathrm{Pb}, \mathrm{Cu}, \mathrm{Fe}, \mathrm{Cd}$ and $\mathrm{Zn}$ and according to Lindsay and Norvel (1978).

\section{Water sampling and analyses}

Water samples analyses were carried out according to the standard methods for examination of water and water waste (APHA 1998). The determind properties and parameters were measured: $\mathrm{pH}$ values were determined by bench-top $\mathrm{pH}$ 

of Kafr-Saqr, El-Sharkia, Egypt

/ ISE meter. Electrical conductivity (EC) at $25 \mathrm{C}^{\circ}$ as standard temperature using ATC bench electric conductivity meters. Total dissolved salts (TDS) calculated from EC values. Total suspended solids (TSS) determined in residue from $100 \mathrm{~mL}$ water sample through evaporation to dryness at $105^{\circ} \mathrm{C}$. The Turbidity test determined by HACH-RATIO / XR- or turbidly meter with gelex secondary turbidity standards 1800, 180, 18, 1.8 Nephlometric Turbidity Unite, (NTU). Biochemical Oxygen Demand [5 days test $\left.\left(\mathrm{BOD}_{5}\right)\right]$ : was determined using ORION BOD fast respirometry system model 890 with a measuring range of $0-4000 \mathrm{mgL}^{-1}$ at $20^{\circ} \mathrm{C} / 5$ days incubation in a thermostatic incubator chamber model WTW.Chemical Oxygen Demand (COD): in the chemical oxygen demand test, the sample is heated at $105^{\circ} \mathrm{C}$ for two hours with a strong oxidizing agent, potassium dichromate $\left(\mathrm{K}_{2} \mathrm{Cr}_{2} \mathrm{O}_{7}\right)$. Oxidizable organic compounds react, reducing the dichromate ion $\left(\mathrm{Cr}_{2} \mathrm{O}_{7}\right)^{-2}$ to green chromic ion $\left(\mathrm{Cr}^{+3}\right)$. The amount of dichromate remaining measured calorimetrically to determine the oxygen demand. The COD reagent also contains silver and mercury ions. Silver is a catalyst, and mercury is used to remove chloride interference. Total alkalinity: for water samples were calculated from the summation of measured carbonates and bicarbonates of each sample and recorded in $\mathrm{mg} \cdot \mathrm{L}^{-1}$ according to APHA (1998). Sodium adsorption ratio (SAR): sodic hazards were expressed by the SAR for irrigation water according to Suarez (1981) through the following Equation:

$$
S A R=N a / \sqrt{(C a+M g) / 2}
$$

where $\mathrm{Na}^{+}, \mathrm{Ca}^{2+}$ and $\mathrm{Mg}^{2+}$ are expressed in meq. $\mathrm{L}^{-1}$. Soluble Cations i.e. $\mathrm{Na}^{+}, \mathrm{K}^{+}, \mathrm{Ca}^{2+}$ and $\mathrm{Mg}^{2+}$ as well as soluble anions i.e. $\mathrm{Cl}^{-}, \mathrm{HCO}_{3}^{-}$ , $\mathrm{CO}_{3}^{-2}$ and $\mathrm{SO}_{4}^{-2}$ were analysed using lon Chromatography (IC) model DX-2500. Heavy metals such as $\mathrm{Cd}, \mathrm{Cu}, \mathrm{Fe}, \mathrm{Pb}$ and $\mathrm{Zn}$ were measured using the Inductively Coupled Plasma-Emission Spectrometry (ICP-OES) with Ultra Sonic Nebulizer (USN). Sodium percentage: was calculated using the following equation.

$$
N a \%=N a /(C a+M g+N a+K) * 100
$$

Soluble cation concentrations are in meq. $\mathrm{L}^{-1}$ Guidelines to emphasize the long-term influence of water quality on crop production, soil conditions, on farm management and farmer health are required. Different guidelies were developed worldwide such as; FAO (1985) and WHO (1995) guidelines. Other guidelines were developed locally for Egyptian conditions such as DWIP guidelines (1997), and NAWQAM guidelines (2007).

\section{RESULTS AND DISCUSSION}

\section{Assessment of the quality of water resources used for irrigation}

Water suitability for irrigation depends on different parameters such as $\mathrm{pH}$ values, total concentration of soluble salts, sodium concentration and its proportion to calcium plus magnesium, bicarbonate content and concentration of boron as well as other toxic substances such as chloride, nitrate and heavy metals that may have local importance for particular soils or crops (FAO, 1976).

\section{$\mathrm{pH}$ value}

The $\mathrm{pH}$ value is one of the most important parameters need for assessing water quality and it represents the instantaneous hydrogen ions activity and influences many biological and chemical processes within water. The $\mathrm{pH}$ values for the irrigation water resources used in the investigated locations are shown in (Fig. 1) mean $\mathrm{pH}$ values of the collected water samples ranged from 7.14 to 7.17 , from 7.43 to 7.45 and from 7.67 to 7.68 , in the first, second and third locations, respectively, during the two studied seasons. These values are within the permissible limits, (FAO, 1985). This means that the studied samples of the irrigation water resources did not significantly differe in their $\mathrm{pH}$ values, neither between different locations, nor between sampling months. On the other hand, the increasing $\mathrm{pH}$ values of the drainage water (location III) may be attributed to a temporal increase in the sodium ions in the drainage water. 


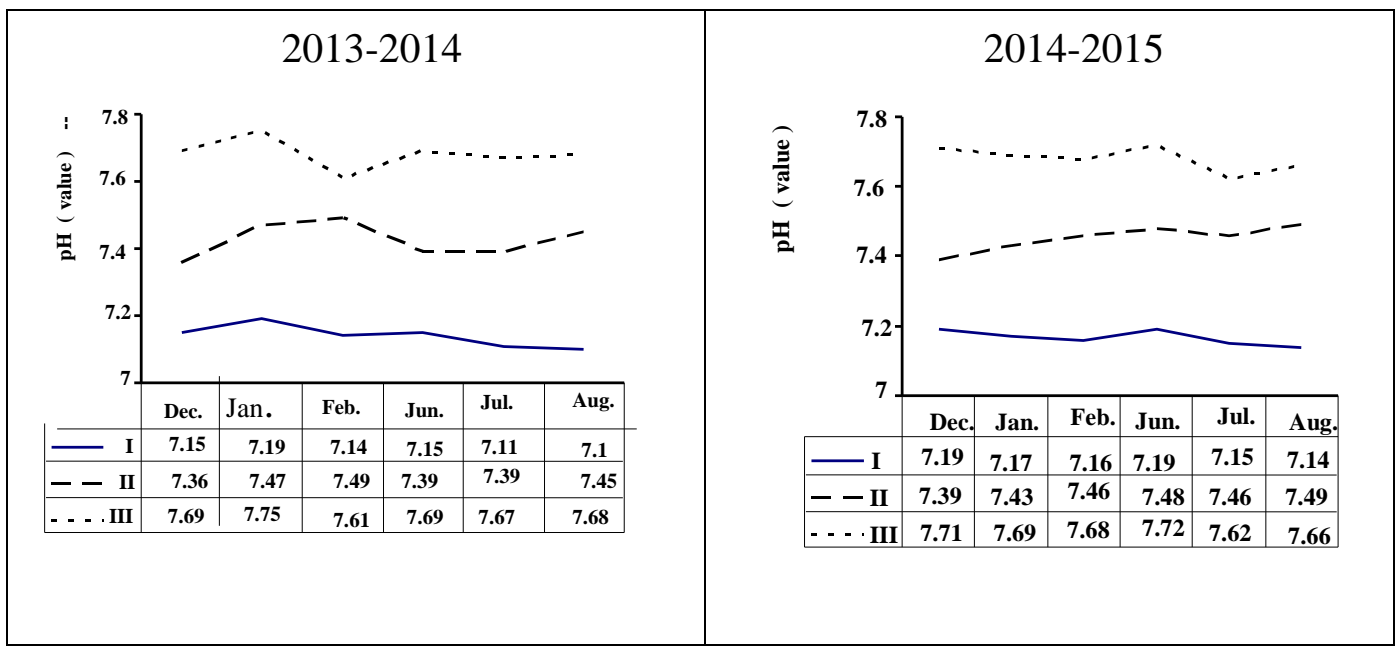

Fig. 1. The $\mathrm{pH}$ values of the different irrigation water resources during the two studied seasons

Where: I. means the first location, II means the seconde location, and III means the third one

\section{Salinity}

EC and TDS values (Figs. 2 and 3) indicated that the values of the irrigation water salinity, through the two seasons at different locations, are higher for drainage water than the corresponding values of the mixed and fresh water. The mixed water (location II) and drainage water (location III) have approximately 3.5 and 5.6 times the salinity of fresh water (location I). This reflects the high impact of Bahr Hadus drain on the salinity of irrigation water in location II and III. since the mean EC values ranged from 1.80 to 1.81 and from 2.80 to $2.84 \mathrm{dSm}^{-1}$ for mixed and drainage water respectively

The investigated irrigation water in the first location (fresh water) exhibited EC values, less than $0.75 \mathrm{dSm}^{-1}$. Hence, this water can be used for irrigation purposes for most of the cultivated crops in most soils with no possibility of salinity problems. On the other hand, the EC values of mixed and drainage water were exceeded 0.75 $\mathrm{dSm}^{-1}$ but were still lower $3 \mathrm{dSm}^{-1}$ salinity increasing problems when using such water in irrigation for prolonged time according to Ayers and Westcot (1985).

\section{Total suspended solids (TSS)}

The removal of suspended solids in water systems depends primarily on gravity sedimentation, and the velocity able to carry out the bigger equivalent diameter of suspended matter (EL-Sayed 1997). The mean values of the total suspended solids in the fresh water (location I) ranged from 319 to $325 \mathrm{mgL}^{-1}$; and from 509 to $532 \mathrm{mg} \cdot \mathrm{L}^{-1}$ and 1149 to $1164 \mathrm{mgL}^{-1}$ in the mixed and drainage waters, (Fig. 2) respectively. This means that the drainage water exhibited a remarkable increase of TDS over the fresh water.

\section{Turbidity}

Turbidity is a measure of fine suspended matter in water, mostly caused by colloidal particles such as clay, silt, non-living organic particulates, plankton and other microscopic organisms, in addition to suspended organic and inorganic matter. Data in (Fig. 3) showes that the values of turbidity mainly differed according to the resource of irrigation water. The mean turbidity values throughout the both seasons ranged between 10.0 to 12.0 nephelometric turbidity unit (NTU) in the fresh water (location I), and from 41.9 to 49.9 NTU in the mixed water. On the other hand, the turbidity values of the drainage water (location III) ranged 

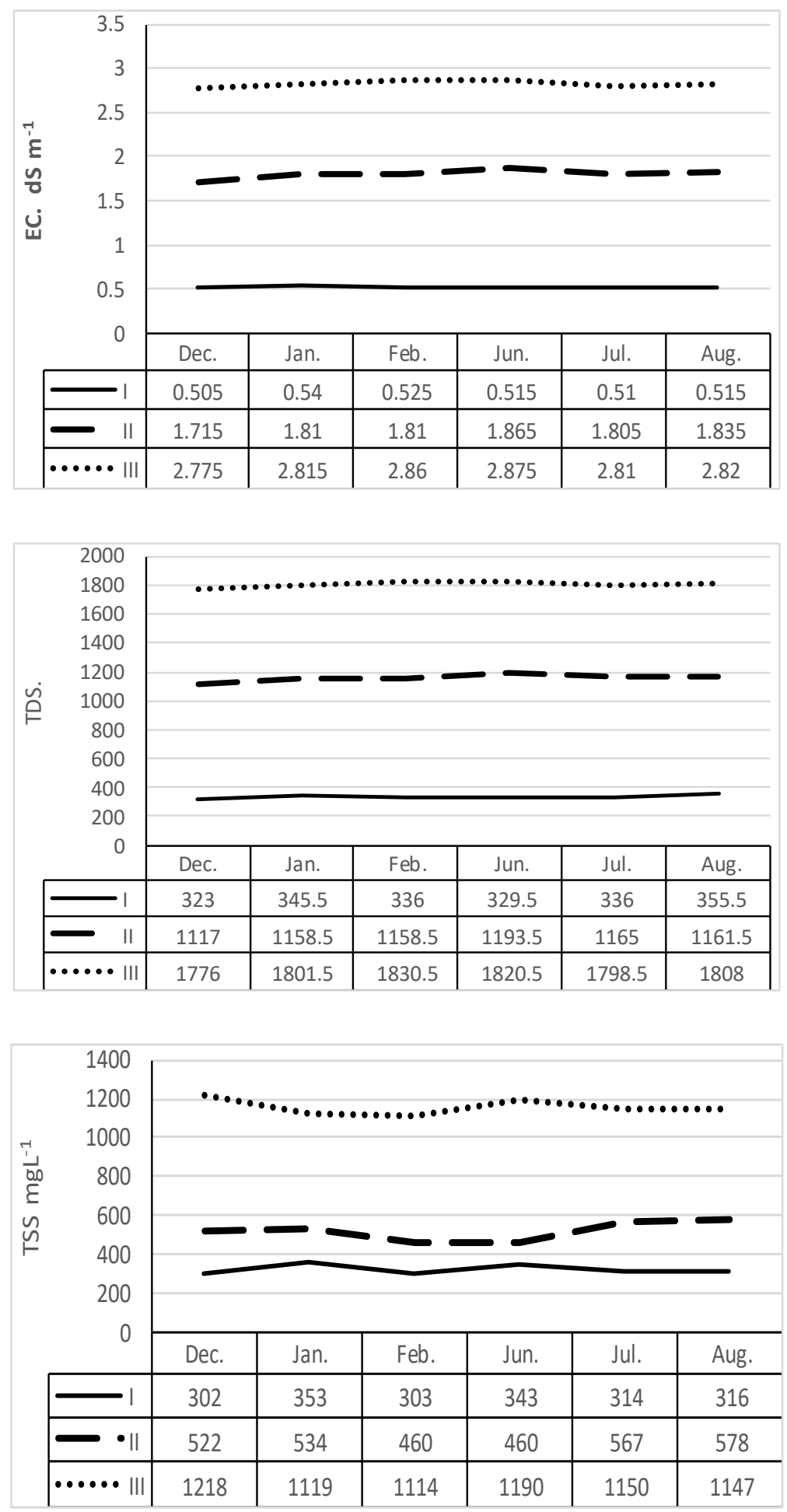

Fig. 2. EC, TDS and TSS average values of the different irrigation water resources in the two studied seasons 


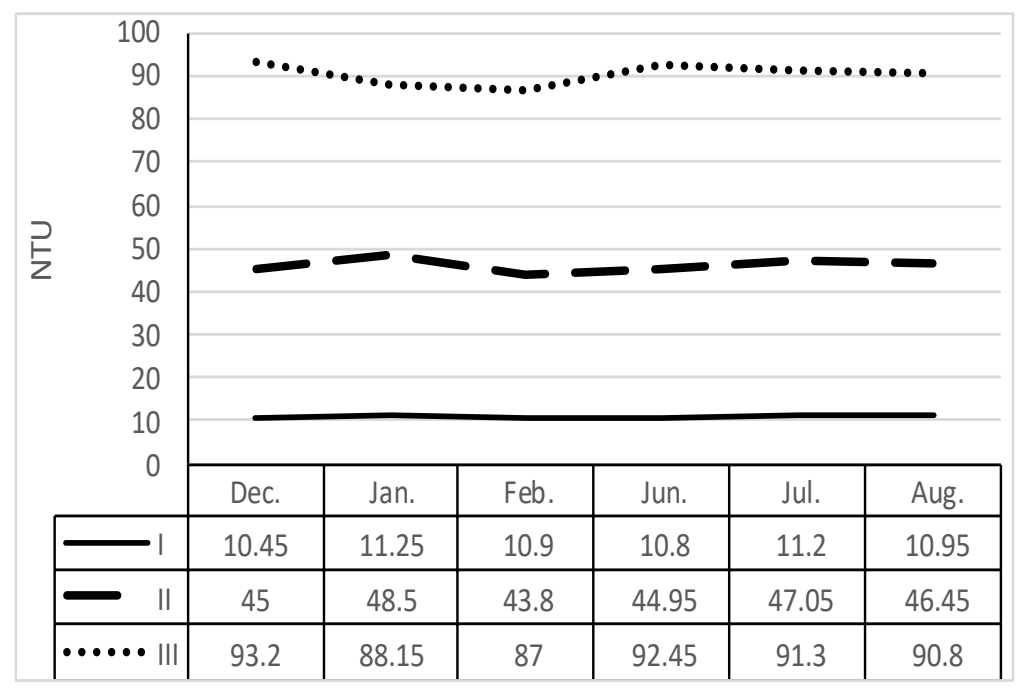

Fig. 3. Turbidity average values (NTU) of the different irrigation water resources in the two studied seasons

between 86.2 to 94.6 NTU. This indicated that both the mixed and drainage waters have higher amounts of suspended materials than the fresh water.

\section{Soluble lons}

The highest values of soluble ions were recorded for the drainage water, while the lowest ones are recorded in the fresh water. Also, there is a marked impact of Bahr Hadus drain on the values of soluble ions in the mixed water.

\section{Major Cations}

Data values of the major cations determined in the water samples from the different locations as well as, SAR and $\mathrm{Na} \%$ are shown in (Fig. 4) The results show that, in the fresh water (location I) the soluble cations were in the order of $\mathrm{Ca}^{2+}>\mathrm{Mg}^{2+}$ $>\mathrm{Na}^{+}>\mathrm{K}^{+}$for the both seasons. In contrast, in the mixed water (location II) and drainage water (location III), the soluble sodium ions are the dominant ions followed by $\mathrm{Mg}^{++}$ions in the mixed water, or $\mathrm{Ca}^{2+}$ ions 'in the drainage water. Potassium ions were the least abundant cation in both studied seasons. There is no doubt that sodium adsorption ratio (SAR) and sodium soluble percent $\left(\mathrm{Na}^{+} \%\right)$ are used to evaluate the suitability of water for irrigation. These values estimated the degree to which sodium will be absorbed by the soil. Data showed that the SAR values of the fresh water (location I) were $<1.0$ while the soluble $\mathrm{Na}^{+} \%$ range between 19.7 and $19.4 \%$ in both seasons. This mean that water sodium hazard is very low, and this water can be used for irrigation without any problems for both soil and plants. On the other hand, the SAR values of the mixed water (location II) and drainage water (location III) ranged from 2.69 to 2.62 and from 3.68 to 3.76 , respectively, and while soluble $\mathrm{Na}^{+} \%$ were slightly exceeded $70 \%$ (Fig. 5). This means that water sodium hazard is very small and the use of mixed and drainage water for irrigation is safe, because the impact of SAR values correlate to EC values. According to Ayers and Westcot (1985) and FAO (1985) SAR must be $<3$. High values of SAR and $\mathrm{Na}^{+} \%$ imply that the sodium ions in the irrigation water replace the $\mathrm{Ca}^{++}$and $\mathrm{Mg}^{++}$ions in the soil, potentially causing damage to soil structure by restricting water movement and hence affecting plant growth (Chapman 1996).

\section{Major Anions}

Data in (Fig. 6) show that the mean values of chloride ions through both seasons, range from 103.3 to $115.2,598.5$ to 618.2 and 1069.7 to $1018.9 \mathrm{mgL}^{-1}$ in the fresh, mixed and drainage water, respectively. Meanwhile, the mean values of sulphate $\left(\mathrm{SO}_{4}{ }^{\circ}\right)$ ions ranged from 131.7 to 127.3 $\mathrm{mg} \cdot \mathrm{L}^{-1}$ in the fresh water, 372.3 to $400.6 \mathrm{mgL}^{-1}$ in the mixed water, and from 608.5 to $632.8 \mathrm{mgL}^{-1}$ in the drainage water. 

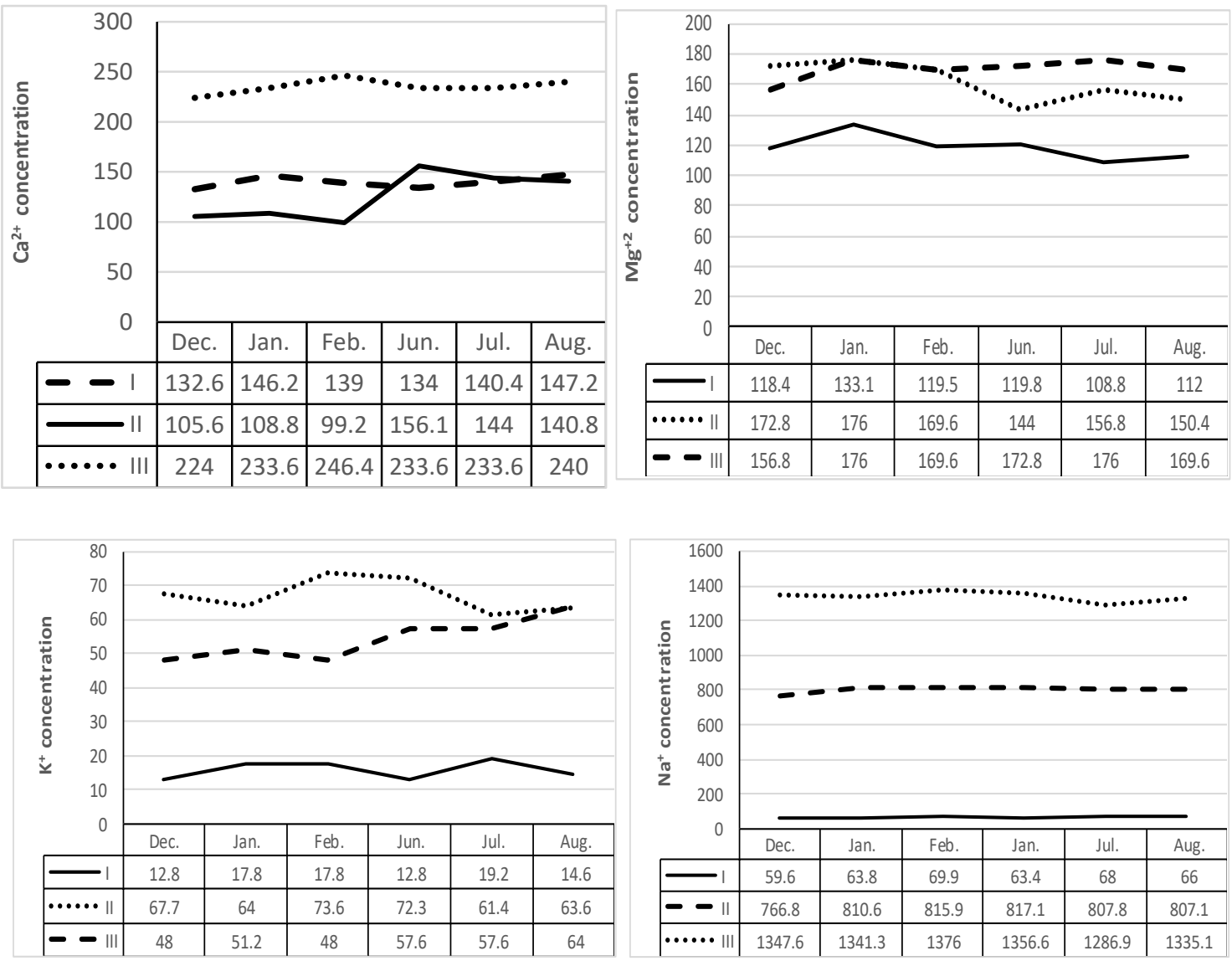

Fig. 4. Average values of soluble cations $\left(\mathrm{mgl}^{-1}\right)$ of the different irrigation water resources in the two studied seasons
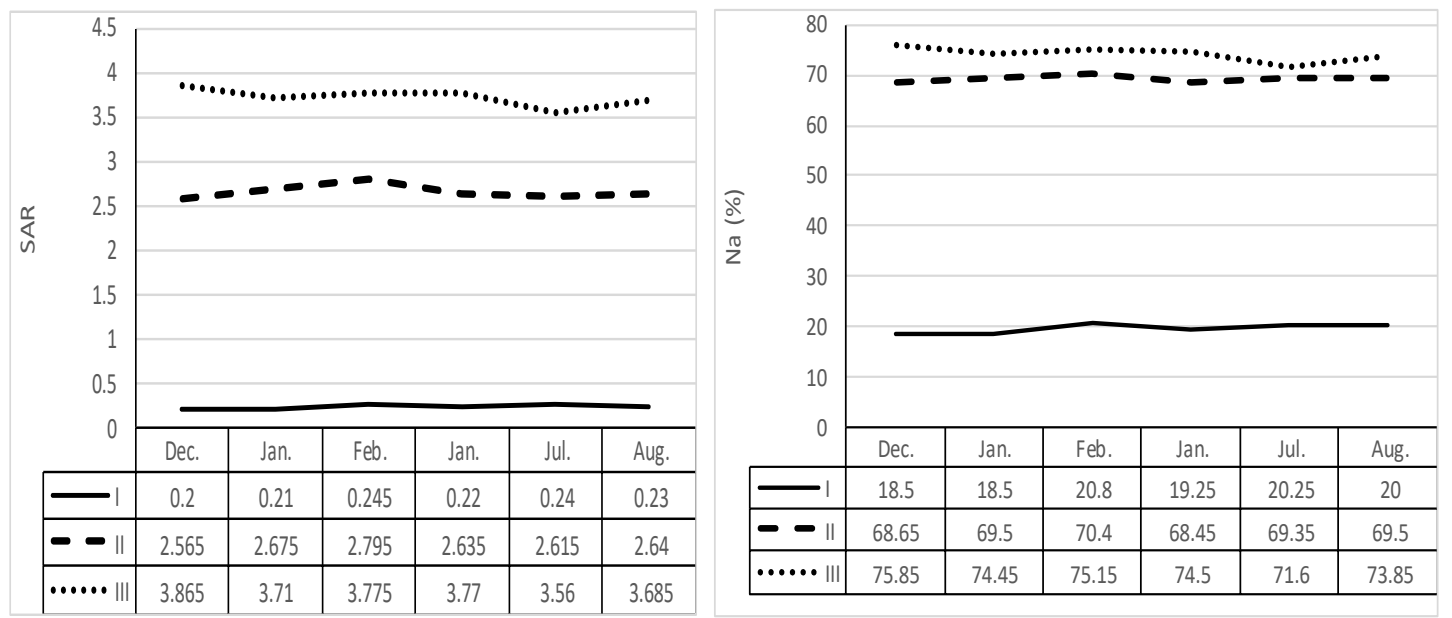

Fig. 5. SAR and Na\% average values of the different irrigation water resources in the two studied seasons. 

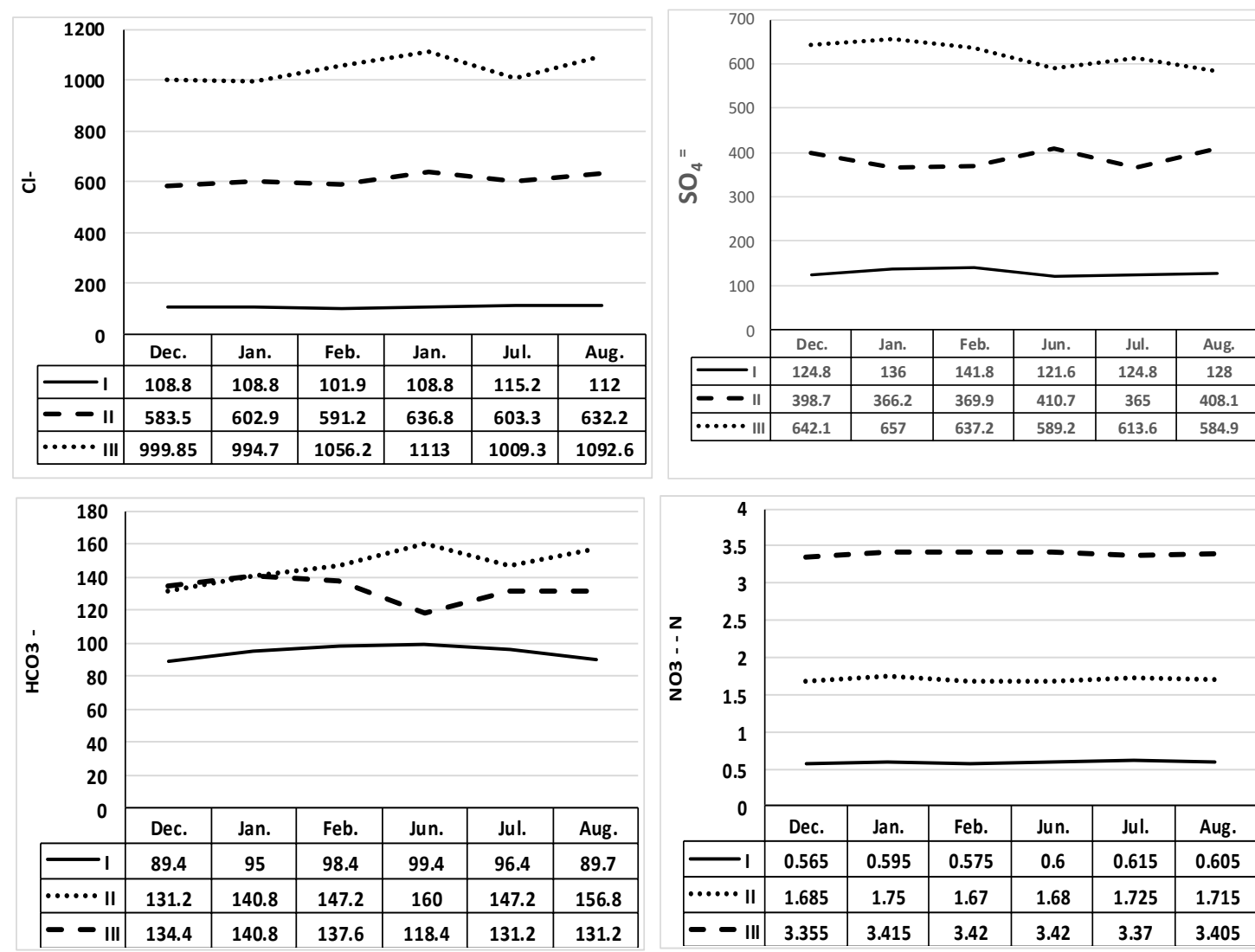

Fig. 6. Average values of soluble anions $\left(\mathrm{mgl}^{-1}\right)$ of the different irrigation water resources in the two studied seasons.

Conserning the concentration of bicarbonate ions in the different irrigation water resources the data indicated that the mean values of bicarbonate ions $\left(\mathrm{HCO}_{3}{ }^{-}\right)$(Fig. 6) ranged from 99.9 to 89.5 in the fresh water, from 144.0 to 150.4 in the mixed water, and in the drainage irrigation water it ranged between 123.7 and $140.8 \mathrm{mg} \cdot \mathrm{L}^{-1}$. This means that all collected irrigation water samples from different locations are within the permissible limits (150 $\mathrm{mg} . \mathrm{L}^{-1}$ for fresh water, and $200 \mathrm{mg} \cdot \mathrm{L}^{-1}$ for drainage water according to law $48 / 1982$. Accordingly, the obtained results showed that the chloride ions $\left(\mathrm{Cl}^{-}\right)$ are the dominant anions followed by sulphate ions $\left(\mathrm{SO}_{4}{ }{ }^{\prime}\right)$ and then bicarbonate ions $\left(\mathrm{HCO}_{3}{ }^{-}\right)$in the mixed and drainage water resources during both studied seasons. Meanwhile, sulphate ions were the dominant ions followed by chloride ions then bicarbonate in the fresh water. The data indicated that all collected samples of irrigation water are contaminated with $\mathrm{NO}_{3}$. (Fig. 6). The mean values of nitrate ions ranged from 0.59 to $0.60 \mathrm{mg} \cdot \mathrm{L}^{-1}$ in the fresh water, from 1.67 to $1.74 \mathrm{mgL}^{-1}$ in the mixed irrigation water, and from 3.38 to $3.42 \mathrm{mgL}^{-1}$ in the drainage irrigation water during the two seasons. These results insured that the concentration of $\mathrm{NO}_{3}$ in all collected samples of irrigation water were lower than the permissible limits. i.e. less than $5 \mathrm{mgL}^{-1}$ according to FAO (1976). Using the mixed and drainage waters for irrigation increased the concentration of $\mathrm{NO}_{3}$ by about 2.9 and 5.7 times compared to using fresh water. This means that using the mixed and drainage water for irrigation for a long time may cause problems for sensitive crops.

\section{Bioclogial Oxygen Demand (BOD)}

Biological oxygen demand (BOD) is used to express the organic pollutants in water which are determined by measuring the oxygen consumption by bacteria. BOD measurements involve determining the amount of dissolved oxy- 

of Kafr-Saqr, El-Sharkia, Egypt

gen required by bacteria to decompose organic materials in water through aerobic biochemical action. Data in (Fig. 7) reveal that all values of BOD violate the standard limits of law $48 / 1982$ except for the BOD values of the fresh water (10 $\mathrm{mgL}^{-1}$ for drains and $6 \mathrm{mgL}^{-1}$ for fresh water). This means that the mixed and the drainage irrigation water are polluted with organic compounds.

The mean values of BOD (Fig. 7) in both seasons were 5.15 and $4.80 \mathrm{mg} . \mathrm{L}^{-1}$ for fresh water (location I), and 16.8 and $16.3 \mathrm{mgL}^{-1}$ for the mixed water (location II), and 29.3, and $289 \mathrm{mg}^{-\mathrm{L}^{-1}}$ for the drainage water (location III). These values reflect higher levels of organic loads in the mixed and drainage water than fresh water. These organic materials may be from sewage or urban discharge.

\section{Chemical Oxygen Demand (COD)}

The chemical oxygen demand (COD) is a measure of the susceptibility to oxidation of the organic and inorganic materials present in water. COD is used to express the organic pollutants in water as determined by chemical oxidation by using potassium dichromate. COD values of mixed and drainage water violate the standard limits (15 $\mathrm{mgL}^{-1}$ for drainage water and $10 \mathrm{mgL}^{-1}$ for the fresh water). The COD concentrations (Fig. 7) in all the investigated irrigation water resources were in the ascending order of Fresh water $<$ mixed water $<$ drainage water.

\section{Heavy metals}

In the present study, five heavy metals were determined in the different collected irrigation water samples. These metals are cadmium (Cd), copper $(\mathrm{Cu})$, iron $(\mathrm{Fe})$, lead $(\mathrm{Pb})$ and zinc $(\mathrm{Zn})$. The data in (Fig. 8) indicate that all of the studied metals didn't violate the allow the able limits of irrigation water according to FAO (1985), the limits being, $\mathrm{Cd}\left(0.01 \mathrm{mg}^{-1} \mathrm{~L}^{-1}\right), \mathrm{Cu}\left(0.2 \mathrm{mgL}^{-1}\right), \mathrm{Pb}\left(5.0 \mathrm{mgL}^{-}\right.$ $\left.{ }^{1}\right)$ and $\mathrm{Zn}\left(2.0 \mathrm{mgL}^{-1}\right)$ and the allowable limit for $\mathrm{Fe}$ is $5.0 \mathrm{mgL}^{-1}$. Concerning the first resource of irrigation water (fresh water), results indicate that the cadmium (Cd) concentrations range from 2.7 to 2.0 $\mathrm{MgL}^{-1}$ as mean values of both studied seasons. Also, the results showed no significant differences during months to in both seasons. The results of Cd (Fig. 8) for mixed and drainage water, indicate that the mean seasonal values range from 5.0 to
3.5 and from 8.8 to $9.7 \mu \mathrm{gL}^{-1}$, respectively. This means that using the mixed water and drainage water for irrigation will increase the contamination with Cd metal compared to using fresh water in the irrigation. However, these values of $\mathrm{Cd}$ did not violate the standard limits for irrigation water, according to FAO (1985). The copper (Cu) concentrations, as reported in and illustrated in reveal that the $\mathrm{Cu}$ values in the different irrigation water resources range from 62.0 to $61.0 \mathrm{\mu gL}^{-1}$ the fresh water, from 75.0 to $74.0 \mathrm{\mu gL}^{-1}$ in the mixed water, and from 96.0 to $100.0 \mathrm{\mu gL}^{-1}$ in the drainage water. These results insure that the concentration of $\mathrm{Cu}$ in the different resources of irrigation water did not violate the allowable limits $\left(1 \mathrm{mgL}^{-1}\right)$ according to law 48 / 1982 and FAO limits for the irrigation water.

The results also indicate that the mean values of $\mathrm{Fe}$ concentrations in the different irrigation waters used in this study ranged from 171 to 175,485 to 493 and 939 to $935 \mathrm{\mu gL}^{-1}$ for fresh, mixed and drainage water, respectively. These results show that Fe concentrations did not exceed the permissible limits (1 mg. $\mathrm{L}^{-1}$ ) according to law $48 / 1982$ and FAO limits (1985). Lead concentrations in the fresh water ranged from 15 to $10 \mathrm{\mu gL}^{-1}$ and from 25 to $20 \mathrm{\mu gL}^{-1}$ in the mixed water, while $\mathrm{Pb}$ values range from 46 to $38{\mu \mathrm{gL}^{-1}}^{-1}$ in the drainage water. Therefore, the increasing values of $\mathrm{Pb}$ in the mixed irrigation water were found to be 1.67 to 2.0 folds the corresponding values of the fresh water in both seasons, respectively. Values of $\mathrm{Pb}$ in drainage water are found to be 3.1 and 3.8 folds, in the two successive seasons. However, $\mathrm{Pb}$ concentration didn't violated the allowable limits $\left(0.2 \mathrm{mg} \cdot \mathrm{L}^{-1}\right)$ according to Middlebrooks (1982). Values of zinc (Zn) concentrations ranged from 65 to 59 , from 79 to 72 and from 99 to $92 \mathrm{\mu gL}^{-1}$ in the fresh, mixed and drainage irrigation water, respectively.

The overall assessment of the irrigation water samples indicates they are within the permissible limits of law 48 / 1982 and FAO (1985) guidelines. This mean that all investigated irrigation water resources can be successfully used for irrigation purposes without any restriction or problems. Statistically, data show the values of the least significant differences (LSD) for the relation between the different parameters used for assessing the quality of the different irrigation water resources. Results indicate that the chemical parameters, biological and chemical oxygen demand, and heavy metals concentrations, are mainly highly significantly (Table 2). 

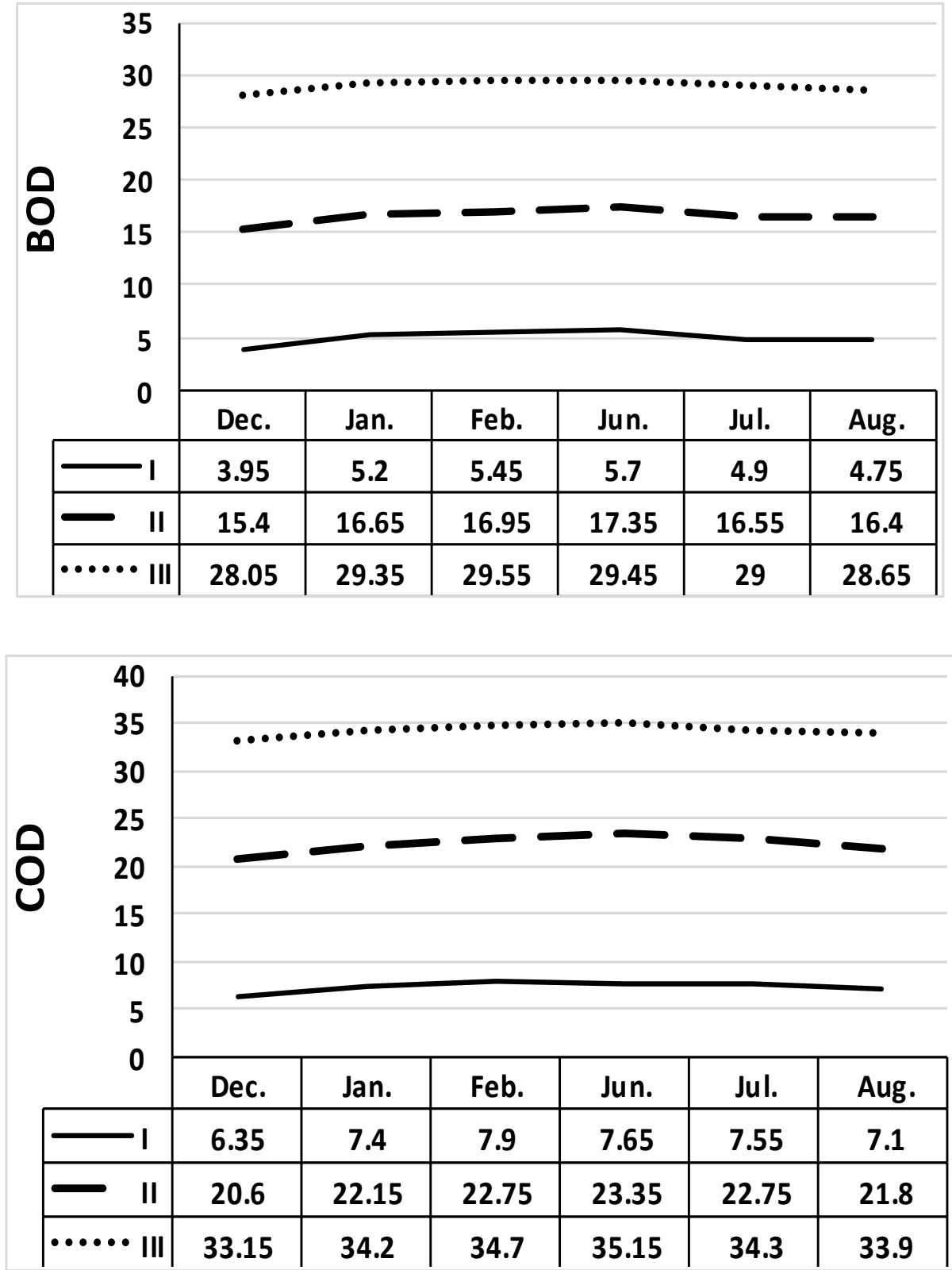

Fig. 7. $B O D$ and COD average values $\left(\mathrm{mgl}^{-1}\right)$ of the different irrigation water resources in the two studied seasons 

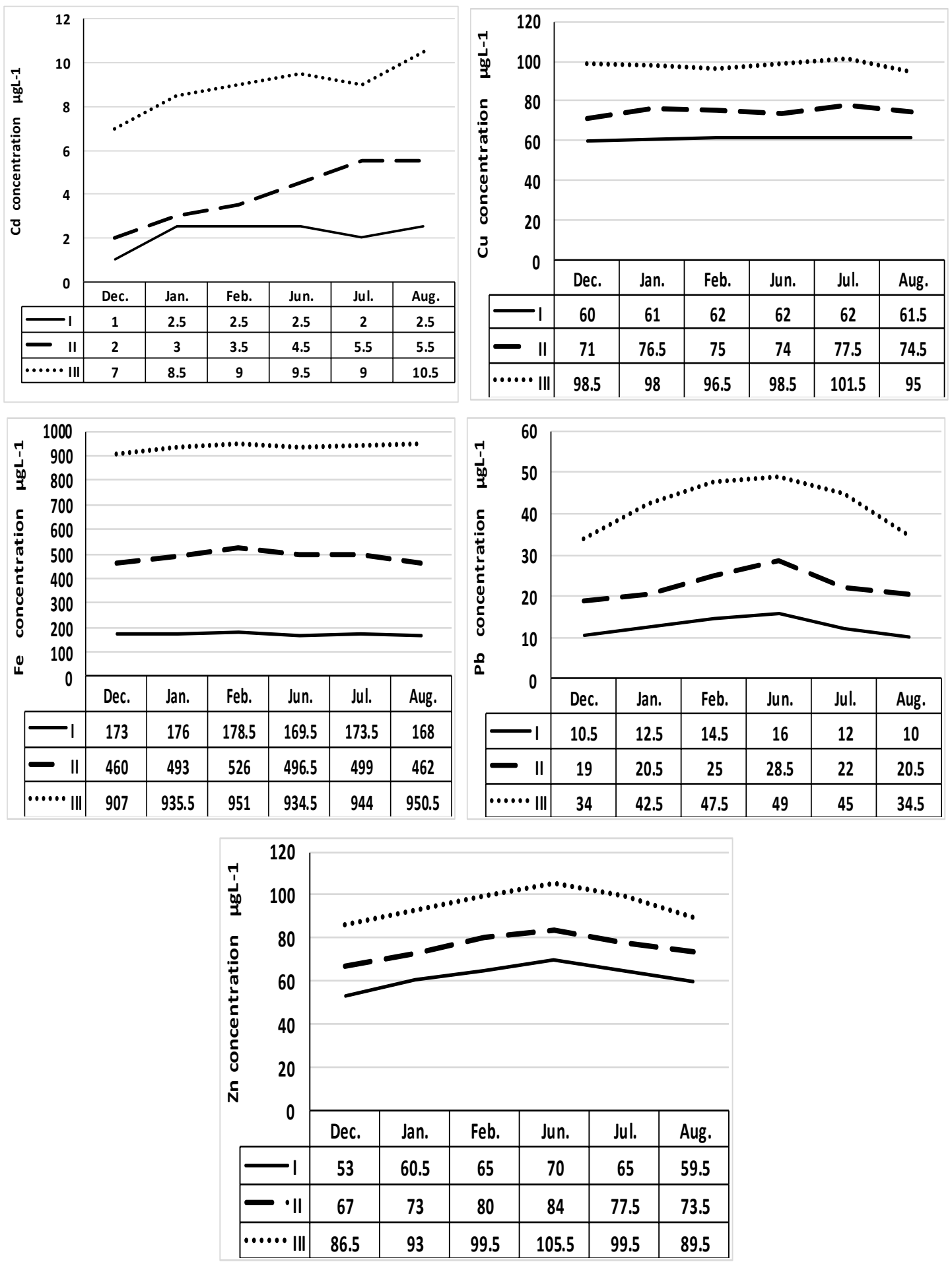

Fig. 8. Average concentrations of heavy metals $\left(\mu \mathrm{gL}^{-1}\right)$ in the different irrigation water resources of the two studied seasons. 
Table. 2. Values of least significant differences (LSD) of the used Parameters in assessing the quality of the different irrigation water resources.

\begin{tabular}{|c|c|c|c|c|c|c|}
\hline \multirow{2}{*}{ No. } & \multirow{2}{*}{ Prameter } & \multirow{2}{*}{ P. } & \multirow{2}{*}{ LSD } & \multicolumn{3}{|c|}{ T.G. } \\
\hline & & & & Fresh & Mixed & Drainage \\
\hline 1 & $\mathrm{pH}$ & 0.0001 & 0.054 & $c$ & $b$ & a \\
\hline 2 & EC & 0.0001 & 0.050 & $c$ & $b$ & a \\
\hline 3 & TDS & 0.0001 & 33.2 & c & $b$ & $\mathrm{a}$ \\
\hline 4 & Turbidity & 0.0001 & 2.08 & $c$ & $b$ & $\mathrm{a}$ \\
\hline 5 & TSS & 0.0001 & 0.0705 & c & $b$ & a \\
\hline 6 & $\mathrm{Cl}^{-}$ & 0.0001 & 43.694 & c & b & $a$ \\
\hline 7 & $\mathrm{SO}_{4}=$ & 0.0001 & 37.794 & c & $b$ & a \\
\hline 8 & $\mathrm{HCO}_{3}^{-}$ & 0.0001 & 13.503 & c & a & $b$ \\
\hline 9 & $\mathrm{NO}_{3}-\mathrm{N}$ & 0.0001 & 0.0378 & c & $b$ & $\mathrm{a}$ \\
\hline 10 & $\mathrm{Ca}^{++}$ & 0.0001 & 21.28 & b & b & a \\
\hline 11 & $\mathrm{Mg}^{++}$ & 0.0001 & 16.45 & $b$ & $\mathrm{a}$ & a \\
\hline 12 & $\mathrm{~K}+$ & 0.0001 & 10.01 & $b$ & a & a \\
\hline 13 & $\mathrm{Na}+$ & 0.0001 & 31.15 & c & $b$ & $\mathrm{a}$ \\
\hline 14 & SAR & 0.0001 & 0.137 & c & $b$ & a \\
\hline 15 & BOD & 0.0001 & 0.749 & c & $b$ & $\mathrm{a}$ \\
\hline 16 & COD & 0.0001 & 0.969 & c & $b$ & a \\
\hline 17 & Cd & 0.0001 & 2.434 & $b$ & $b$ & a \\
\hline 18 & $\mathrm{Cu}$ & 0.0001 & 3.105 & c & $b$ & $\mathrm{a}$ \\
\hline 19 & $\mathrm{Fe}$ & 0.0001 & 30.757 & c & b & a \\
\hline 20 & $\mathrm{~Pb}$ & 0.0001 & 6.283 & c & $b$ & a \\
\hline 21 & $\mathrm{Zn}$ & 0.0001 & 9.044 & C & $b$ & $a$ \\
\hline
\end{tabular}

Where P. (propability), T.G. (Total group)

Impact of the irrigation water resources on some chemical characteristics of the investigated soil at different locations

\section{Soil reaction ( $\mathrm{pH}$ value)}

Data show that the mean $\mathrm{pH}$ values of soil profile layers (Fig. 9) irrigated with different water resources ranged from 7.62 to $7.60,8.17$ to 8.15 and 8.27 to 8.26 for the soils irrigated with the fresh, mixed and drainage waters in both seasons, respectively. The small increase in $\mathrm{pH}$ values for the soil irrigated with mixed and drainage water, may be attributed to the dominance of $\mathrm{Ca}^{++}, \mathrm{Mg}^{++}$and $\mathrm{Na}^{+}$which are considered as base-forming, meaning that they contribute to an increase of $\mathrm{OH}^{-}$concentration in the soil solution and a decrease in $\mathrm{H}_{+}$ concentration (Miller and Donahue, 1995). On the other hand, the alkali hazard involved in the use of water for irrigation is determined by the absolute and relative concentrations of cations. If the proportion of sodium is high, the alkali hazard is high; and conversely if $\mathrm{Ca}^{++}$and $\mathrm{Mg}^{++}$predominate, the hazard is low.

\section{Electerical Conductivity (EC)}

Data (Fig.10) indicate that continuous irrigation of soil by using wastewater resulted in continuous increase in the electrical conductivity values. Consequently, the mean values of EC, calculated as a mean soil profile, for the soil irrigated with fresh water ranged between 1.14 to $1.23 \mathrm{dS} . \mathrm{m}^{-1}$. Otherwise EC. values for the soil irrigated with mixed water range between 1.31 to $1.32 \mathrm{dS} . \mathrm{m}^{-1}$. Meanwhile EC value of the soil irrigated with the drainage water ranged from 1.93 to $1.91 \mathrm{dS} . \mathrm{m}^{-1}$. This means that salts accumulation of salts as a result of using wastewater for irrigation is of greater magnitude, especially in heavy textured soil (Table 1). The values of EC. in all layers of the investigated soils profiles were generally $<4 \mathrm{dSm}^{-1}$. Therefore, these soils are classified as non-saline soil. On the other hand, the observed changes in the accumulation of the total soluble salts on the surface layers in the first and second locations may be due to capillary conductivity and evaporation from surface layers. In contrast, the increase of the soluble salts at the lower soil layer in location III 


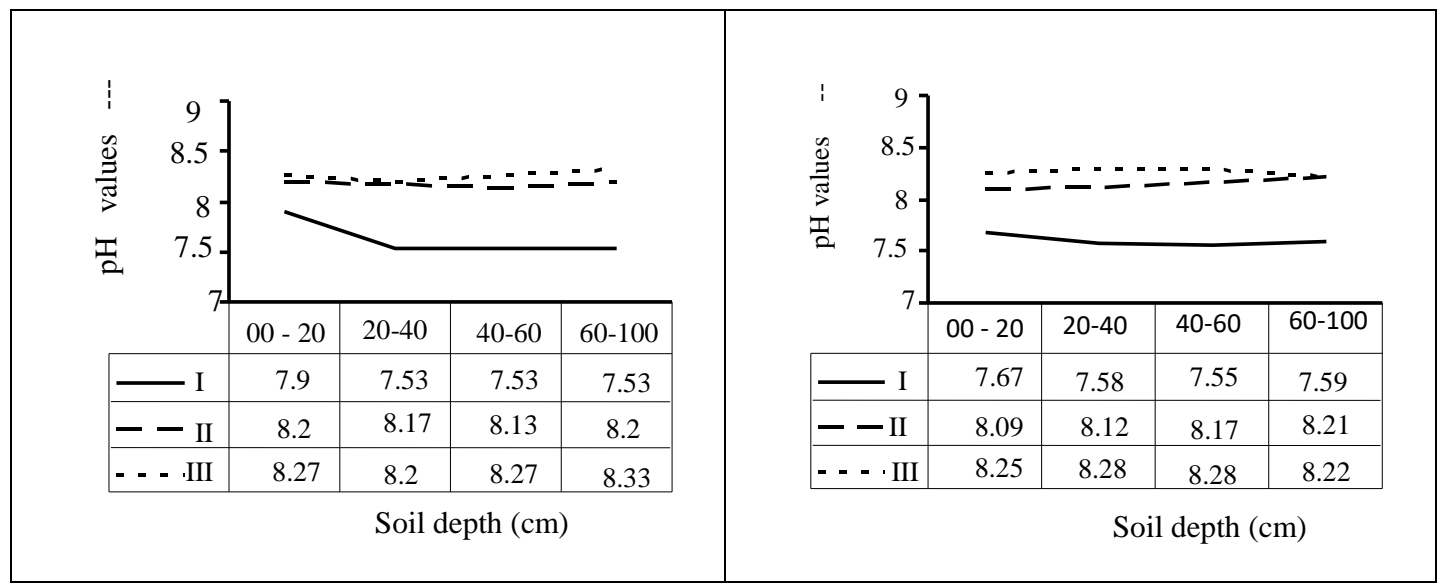

Fig. 9. $\mathrm{pH}$ values of the different soil layers in the studied locations at both seasons.

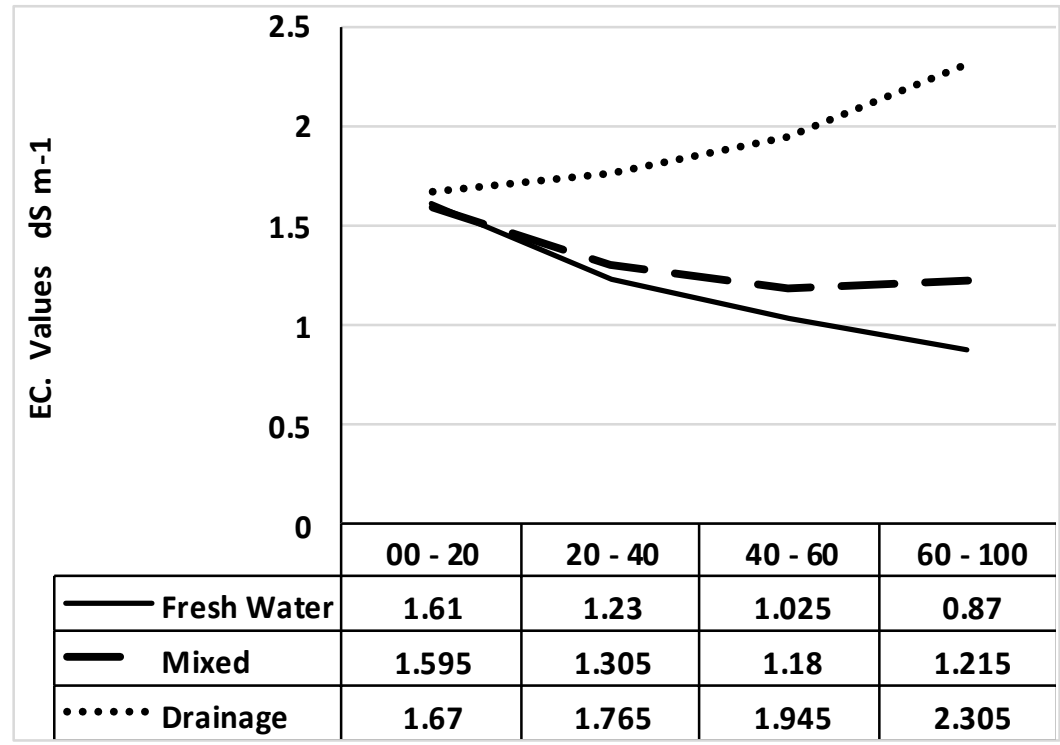

Fig. 10. EC average values ( $\mathrm{dS} \mathrm{m}^{-1}$ ) of the different soil layers of the studied locations in both seasons.

may be either due to the movement of soluble salts downward with irrigation water or to the fluctuation of water table.

\section{Soluble cations and anions}

Data show in (Figs.11 and 12) the concentrations of the soluble cations and anions and their distribution through the successive soil layers under different resources of irrigation water. The distribution of soluble cations and anions appear to have a similar trend to those obtained for EC values. They mostly decrease with increasing soil depth in the soil irrigated with fresh and mixed water. In contrast, the of soluble cations and anions in the soil irrigated with drainage water showed an opposite trend as they increased with depth. The application of different irrigation waters led to the increases in soluble $\mathrm{Na}^{+}, \mathrm{Ca}^{++}$, and $\mathrm{Mg}^{++}$contents in the soil. The concentration of soluble cations were in the following order of: $\mathrm{Na}^{+}>\mathrm{Ca}^{++}>\mathrm{Mg}^{++}>\mathrm{K}^{+}$Concerning the distribution of the soluble anions, chloride ions were dominant at all soil layers at the three soil locations. Generally, the soluble anions are found in the following order : $\mathrm{Cl}^{-}>\mathrm{SO}_{4}{ }^{=}>\mathrm{HCO}_{3}{ }^{-}$. 

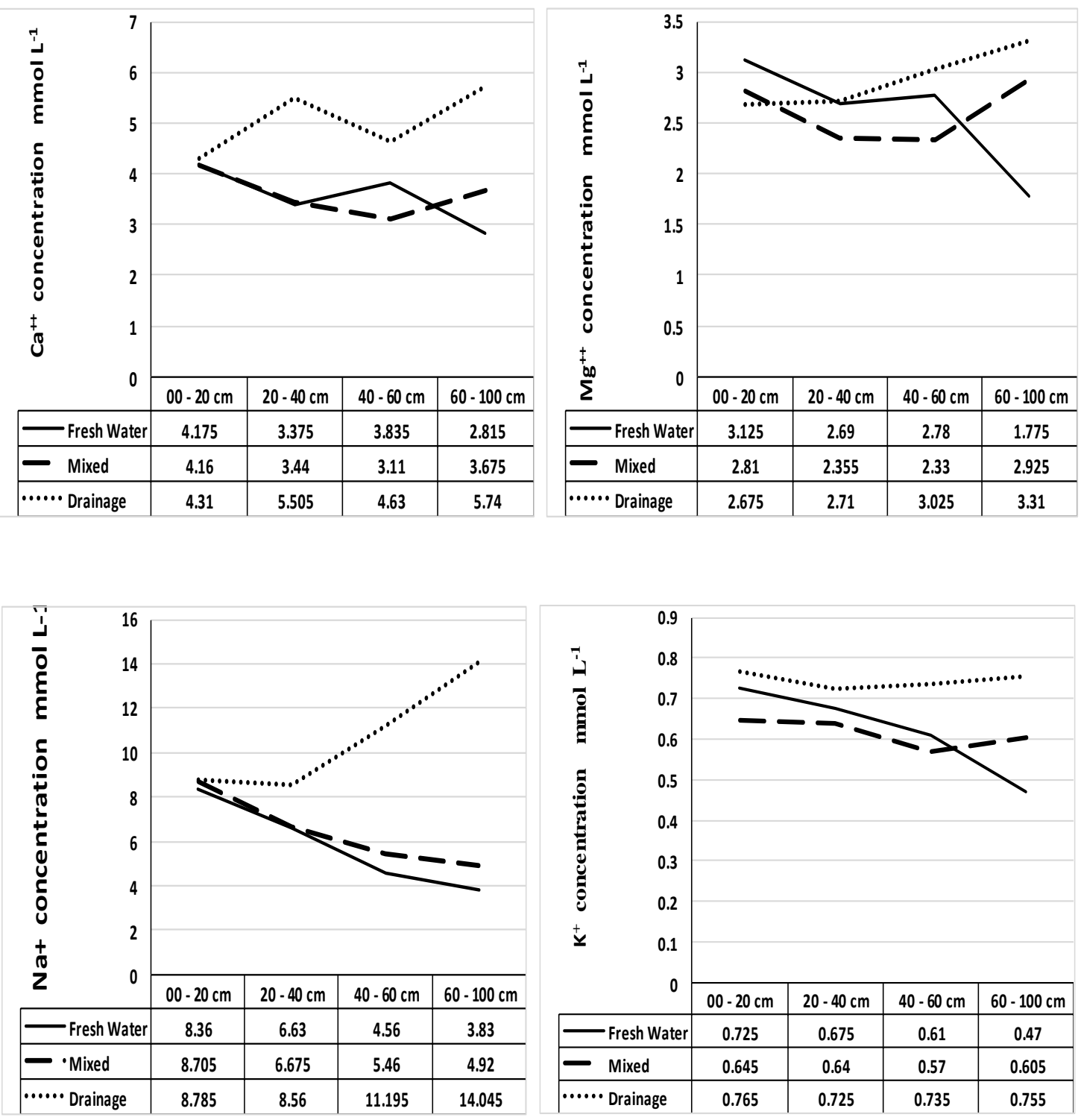

Fig. 11. Average values of soluble cations $\left(\mathrm{mmol} \mathrm{L}^{-1}\right)$ of the different soil layers of the studied locations at both seasons. 

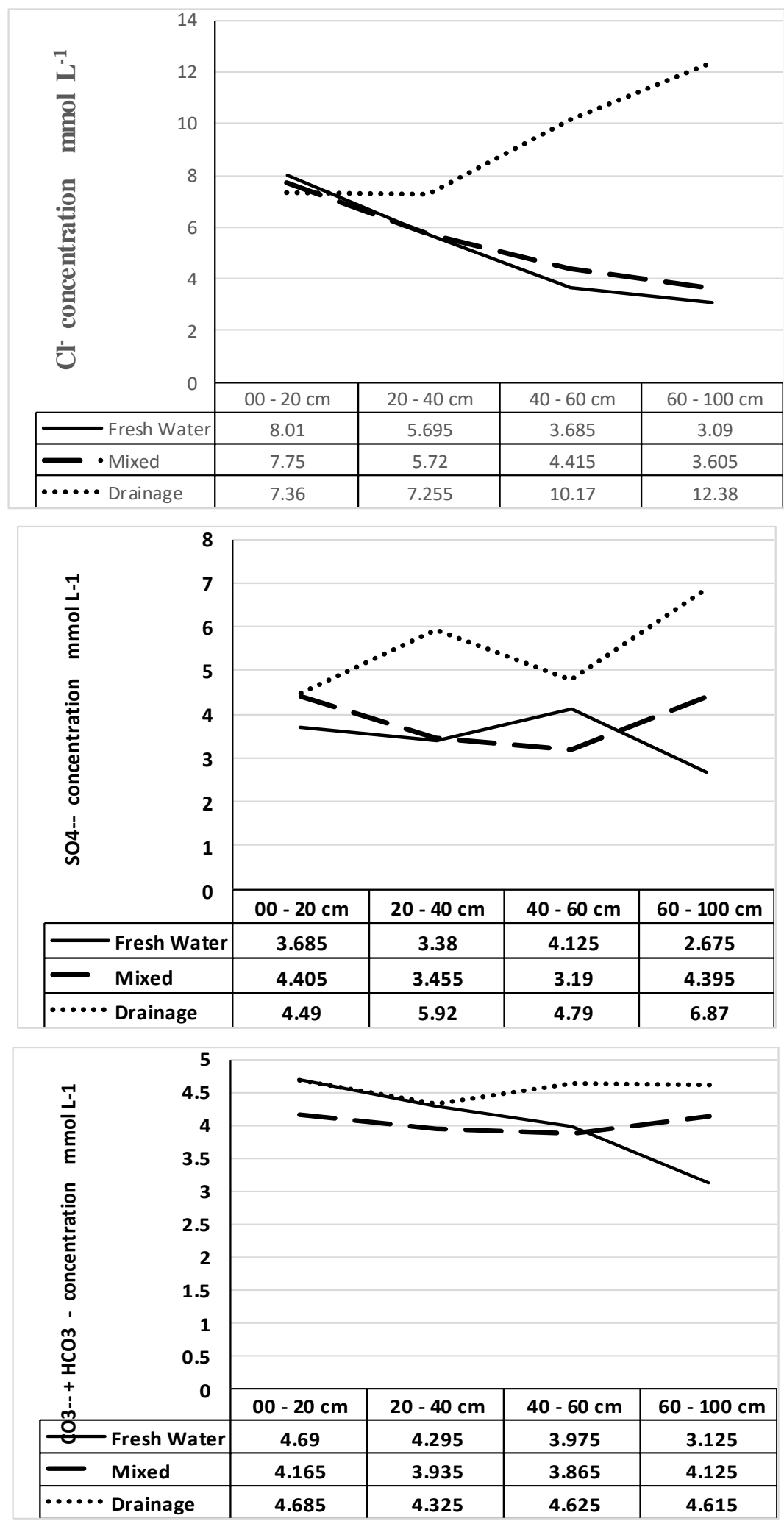

Fig. 12. Average values of soluble anions $\left(\mathrm{mmol} \mathrm{L}^{-1}\right)$ of the different soil layers of the studied locations at both seasons. 

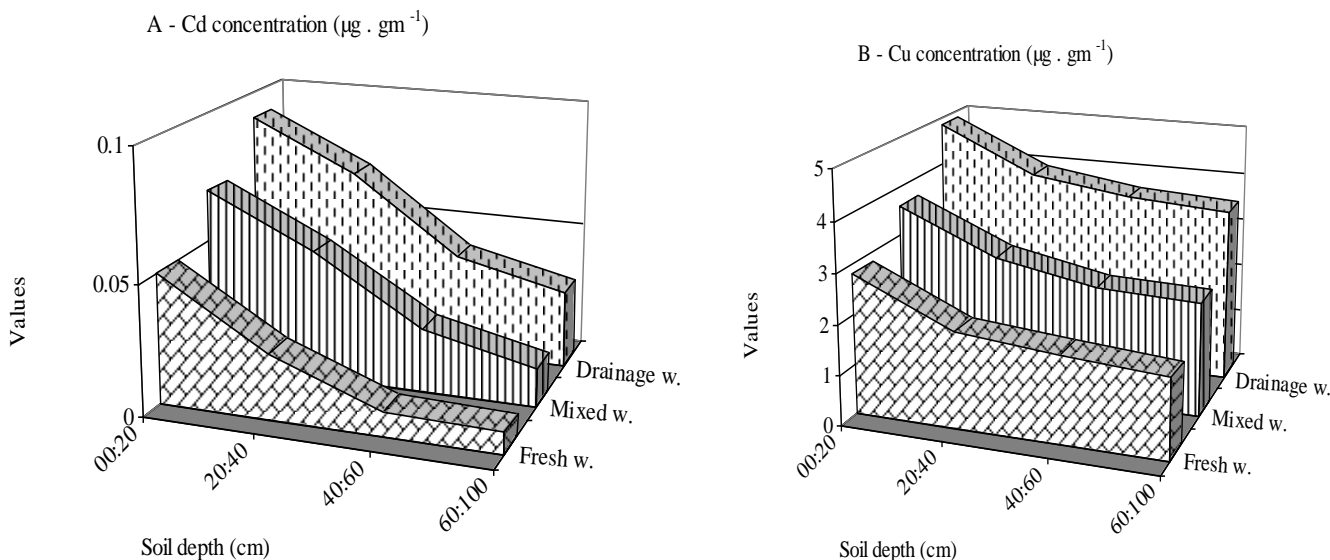

C - Fe concentration $\left(\mu \mathrm{g} \cdot \mathrm{gm}^{-1}\right)$

$\mathrm{D}-\mathrm{Pb}$ concentration $\left(\mu \mathrm{g} \cdot \mathrm{gm}^{-1}\right)$
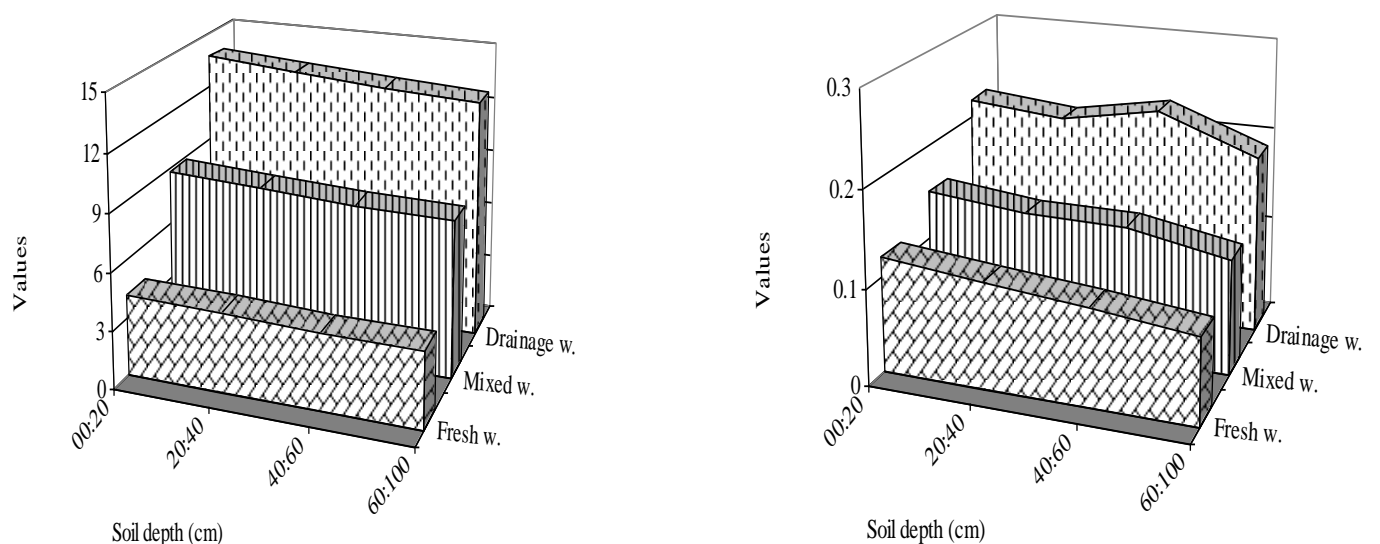

E - Zn concentration $\left(\mu \mathrm{g} \cdot \mathrm{gm}^{-1}\right)$

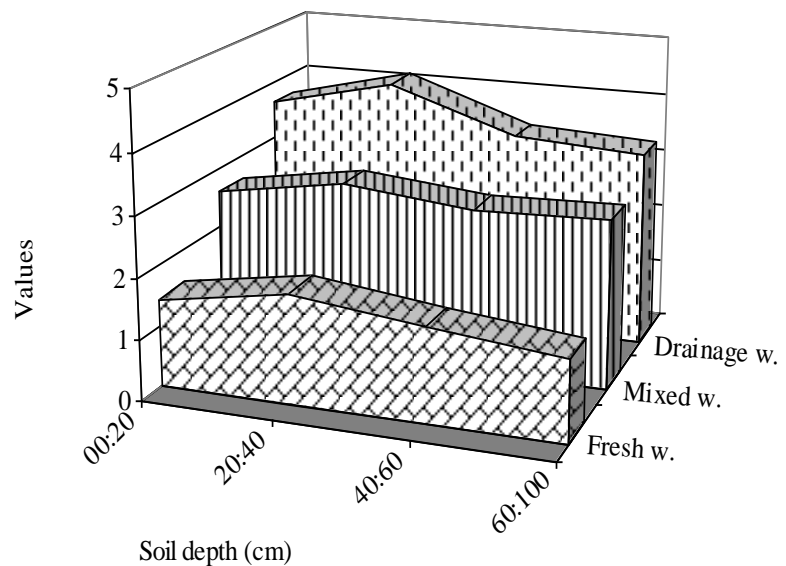

Fig. 13. Impact of irrigation water resources on the concentration of the DTPA extractable heavy metals in the soil. 


\section{Heavy metals content}

Data show in (Fig. 13) the concentrations of DTPA- extractable heavy metals $\left(\mu \mathrm{g} \mathrm{g}{ }^{-1}\right)$ in the different soil layers of the investigated soil profiles. Data reveal that the extractable content of these metals differed according to water resource used for irrigation. Generally, it was noticed that the concentrations of these heavy metals in the different soil profile layers were small, however higher in the two upper soil layers $(0-20$ and $20-40 \mathrm{~cm})$ than the lower ones. The higher concentrations of heavy metals in the surface soil layer $(0-20 \mathrm{~cm})$ of the investigated soil locations, irrigated with mixed water and drainage water, were 1.4 , and 1.8 times for $\mathrm{Cd}, 1.28$ and 1.73 times for $\mathrm{Cu}, 2.11$ and 3.28 times for $\mathrm{Fe}, 1.25$ and 1.83 times for $\mathrm{Pb}$, and 1.80 and 2.52 times for $\mathrm{Zn}$, respectively, compared with these irrigated with fresh water.

\section{REFERENCES}

APHA, 1998. American public health association "APHA". Standard methods for the examination of water and wastewater. Washington, D.C.

Chapman, H.D. 1996. Water Quality Assessments: A guide to the use biota, sediments and water in environmental monitoring. Chapman and Hall $2^{\text {nd }}$ Ed. London Glasgow, Weinheim, New York.

Drainage Research Institute 2005. "Drainage Water Status in the Nile Delta", Year book 2002/2003 Tech. Report No.73.

El-Sayed, A. 1997. Water quality management of drainage systems in the eastern Nile Delta. Ph.D. Thesis, Fac. Eng., Ain Shams Univ., Egypt. 37 p.

FAO. 1976. Soil survey investigations for irrigation. Soil Bull. 42, Rome.

FAO. 1985. Guidelines for interpretation of water quality for irrigation. Adapted from FAO Irrigation and Drainage, Paper No. 29.
Law, 1982. The Implementary Regulations for law 48-1982 Regarding the protection of the River Nile and waterways from pollution. Map. Periodical Bull. 3-4 Dec., pp. 12-35.

Lindsay, W.L. and Norveli, W.A. 1978. Development of DTPA test for zinc, ions magnesium and cupper. Soil Sci. Soc. Am. J., 42, 421.

Middlebrooks, E.J. 1982. 'Waste Water ReuseOn Assessment of the Potential and Technology'. Water Reuse Book. Ann Arbor Science Publishers Inc.

Miller, R.W. and Donahue, R.L. 1995. Soils in Our Environment, $7^{\text {th }}$ Ed. Prudence Hall, Englewood, Cliffs, NJ., p. 323.

NAWQAM, 2007. Operational Drainage Water Reuse Guidelines, DR-TR-0103-006-DR. Drainage research Instiute, NWRC, Cairo, Egypt.

Page, A.L., Miller, R.H. and Keeney. D.R. 1982. 'Methods of Soil Analysis'. Part 2. Chemical and Microbiological Properties, $2^{\text {nd }}$ Ed., Madison, Wisconsin USA.

Patterson, R.A. 1999. Effects of effluent chemistry on soil properties. Production and Environ. Monitoring Workshop. New England Armidale. Unive., Paper PEM009.

Peavy, H.S., Donal, R. and Tchobanoglous. G. 1986. Environmental Engineering. Mc Graw-Hill Book Co., Singapore.

Suarez, D.L. 1981. Relationship Between $\mathrm{pH}$ and SAR as an alternative methed for estimating SAR of soil or drainage water. Soil Sci. Soc. Am. J., 45,469-475.

WHO. 1995. World Health Organization, Health Effects relating to Direct and Indirect Reuse of Wastewater for Human Consumption. Report of an International Working Meeting held at Amsterdam. The Netherlands, January 13-16, 1975, WHO Technical Paper No. 7, 164 p. 